\title{
Impacts of processing heat treatments on deltamethrin and bifenthrin residues in human breast milk and raw milk from different animals
}

\author{
S.A. Abd Al-Zahra ${ }^{1}$ and A.J. Ahmed ${ }^{2}$ \\ ${ }^{1}$ Department of Veterinary Public Health, College of Veterinary Medicine, University of Baghdad, \\ ${ }^{2}$ Department of Animal Production, College of Agriculture, University of Sumer, Dhi Qar, Iraq \\ E-mail: rosemusawy2@gmail.com
}

(Received October 15, 2017; Accepted November 23, 2017)

\begin{abstract}
A total of 163 milk samples $(200 \mathrm{ml})$ human breast milk and $(500 \mathrm{ml}$ each) of cows, ewes, goats, buffaloes and camels were collected randomly at weekly intervals (10 samples/week) from Baghdad governorate. Among the total milk samples (138) milk samples were examined during two climatic periods from the beginning of September 2016 to the end of the February 2017 were tested for the occurrence of DMT residues by using the HPLC technique. Besides that, some of the selected positive samples were subjected to one of the commercial heat treatments such as $63^{\circ} \mathrm{C} / 30 \mathrm{~min}, 80^{\circ} \mathrm{C} / 5 \mathrm{~min}$ and $100^{\circ} \mathrm{C} / 5 \mathrm{~min}$ to evaluate the efficiency of heat exposure on the degradation of deltamethrin and bifenthrin residues in milk. The results pointed out that milk samples containing the higher fat percentage exhibited significantly $(\mathrm{P}<0.05)$ the highest concentration of deltamethrin and bifenthrin in summer highest than in winter, increased the fat percentages of milk was being associated with an increased level of deltamethrin residues due to the lipophilic nature of the deltamethrin and bifenthrin pesticide. The current results revealed that milk samples that were collected from buffaloes, ewes and cows recorded the highest deltamethrin and bifenthrin residues in summer season where their mean levels that exceeded the accepted MRLs of $0.05 \mathrm{ppm}$ to milk samples of goats, camels and breast milk the lowest mean levels of deltamethrin and bifenthrin residues. There was a seasonal variation of the deltamethrin and bifenthrin concentrations in milk samples for each animal species where all the milk samples that were collected from buffaloes, ewes, cows, goats, camels and breast milk had higher mean levels of deltamethrin and bifenthrin residues in summer season than in winter season. Data illustrated revealed that there was a seasonal variation in the mean levels of deltamethrin and bifenthrin residues in human breast milk samples for each district village where all the milk samples that were collected from AL-Sader and AL-Karada districts had highest mean levels values in summer than in winter season.
\end{abstract}

Keywords: High performs liquid chromatography, deltamethrin, bifenthrin, raw milk, Skimmed milk Available online at http://www.vetmedmosul.org/ijvs
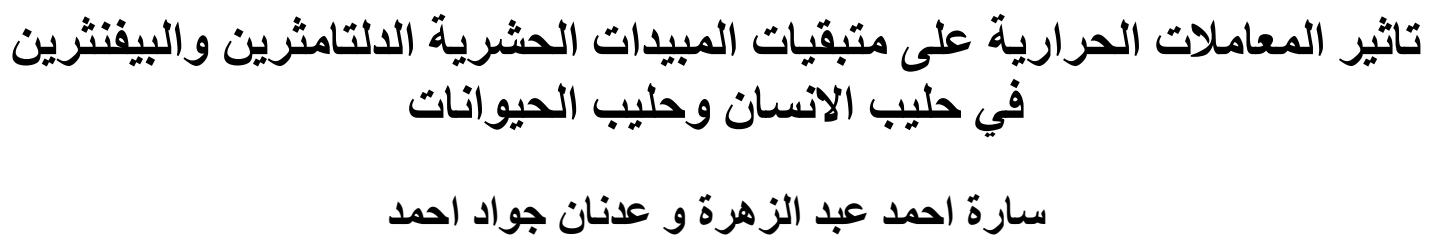

فرع الصحة العامة البيطرية، كلية الطب البيطري، جامعة بغداد، قسم الانتاج الحيواني، كلية الزر اعة، جامعة سومر، ذي قار، العراق

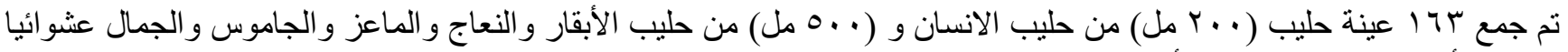

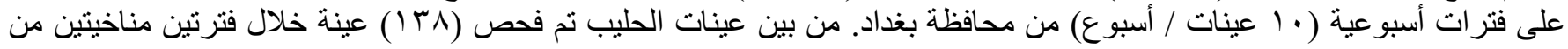

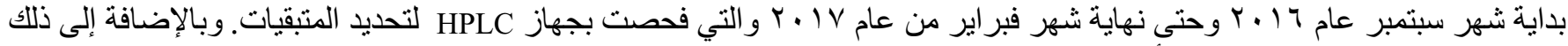

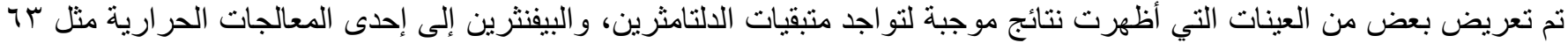




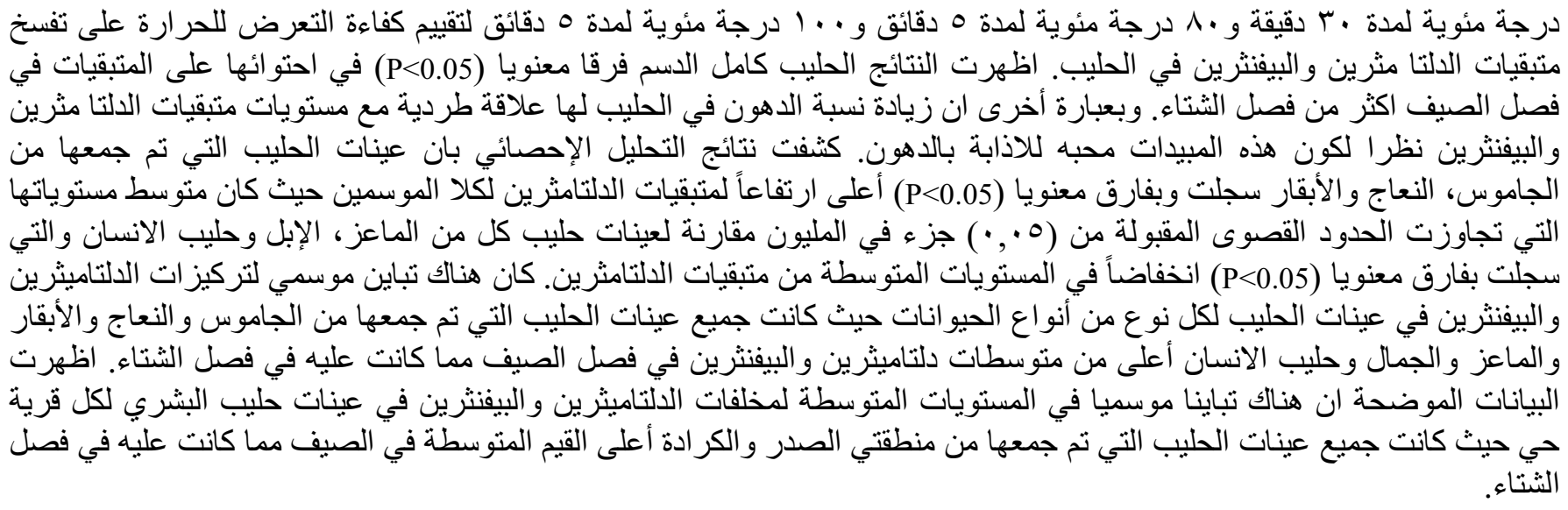

\section{Introduction}

Presence of persistence and hazardous Agrochemicals in the human diet is an emerging problem in developing countries which encounter poor institutional progress and slow financial development.

Deltamethrin is type II synthetic pyrethroid pesticides that produced in 1974 and first marketed in 1977 and the deltamethrin products are among some of the most popular and widely used insecticides in the world in competing ectoparasites affecting farm animals (1). Bifenthrin is an insecticide used heavily in the control of red imported fire ants, due to its high toxicity to aquatic organisms, it is listed as a restricted use pesticide, although it can be purchased for residential use in lower concentrations and It has a very low solubility in water and tends to bind to soil, which minimizes runoff into water sources (2), The Environmental Protection Agency (EPA) has also identified bifenthrin as a class $\mathrm{C}$ carcinogen, meaning that it is a possible human carcinogen (3). The contamination of milk with pesticides is considered as one of the main dangerous aspects in the last few years. Milk has been found to be a very good reference point for monitoring contamination by pesticides (4). To control the presence of pesticide residues in fresh milk and milk products is a big issue for producer, consumer and government due to the potential risk. Human milk as well as animal milk is contaminated through the contaminated food (5). These residues are too much persistent. They accumulate in body fat even in breast milk. Transfers of such pesticide to our body via food of animal origin rich with fat contents such as milk has not been studied till now in Iraq and Since there is no data on the residual levels of deltamethrin and bifenthrin in human breast milk and different animal, this study was conducted to determine the levels of deltamethrin pesticide residues in cow's, ewe's, buffaloe's, goat's, camel's milk samples collected from Baghdad province, using High Performance Liquid Chromatography (HPLC).
The aims of current study were to determine the residues of deltamethrin and bifenthrin in Human breast raw milk, cow's, ewe's, goat's, buffalo's and camel's milk samples collected from different areas in Baghdad province, and comparison of the mean levels of this pesticides residues (ppm) between the cow's raw and skimmed milk samples, and assessing the effect of heat treatment on existentially of deltamethrine and bifenthrin residues in raw milk.

\section{Materials and methods}

This study was carried out during the period extended from the beginning of September 2016 to the end of the February 2017. A total of 175 milk samples they were of 12 milk samples $(200 \mathrm{ml}$ each) of Human breast milk and 163 milk samples (500 $\mathrm{ml}$ each) of cows, ewes, goats, buffaloes, camels were collected randomly from Baghdad and at weekly intervals (10 samples / week) in a sterile polyethylene plastic bags from Baghdad governorate.

All the collected milk samples were transported to the laboratory inside portable ice-cooled containers. 175 milk samples were examined on two climatic periods, the first was the summer period that extended from the beginning of September to the end of October 2016 while the second was the winter period that extended from the beginning of January to the end of February 2017. Each milk sample was divided into two portions where the first portion $(300 \mathrm{ml})$ was used to determine the chemical composition of milk such as the specific gravity and the percentages of fat, lactose, protein, solid not fat and minerals by using the Ultrasonic Milk Analyzer. While the second portion of (200 $\mathrm{ml}$ ) was sent to the HPLC analysis to determine the level of deltamethrine and bifenthrin residues, besides that some of selected positive samples for deltamethrine and bifenthrin residues were subjected to one of the industrial heat treatments such as $63^{\circ} \mathrm{C} / 30 \mathrm{~min}, 80^{\circ} \mathrm{C} / 5 \mathrm{~min}$ and $100^{\circ} \mathrm{C}$ 
$15 \mathrm{~min}$ to determine the effect of heat treatment on the levels of deltamethrime and bifenthrin residues in milk (1).

Data submitted to statistical analysis by using of variance (ANOVA) and using least significant differences (LSD) to differentiate among the means used spss program (6).

\section{Results and discussion}

Comparison of the mean levels of deltamethrin and bifenthrin residues between the full fat and skimmed milk samples

The results illustrated in Table 1 revealed that in raw milk and skimmed milk with fat from $3.29 \%$ to $1.064 \%$ the deltamethrin residues were from 0.113 and $0.00 \mathrm{ppm}$ and bifenthrin residues from 0.134 and $0.00 \mathrm{ppm}$. The current results established the statistically significant $(\mathrm{P}<0.05)$ influence of the fat percentage on the concentration of the deltamethrin and bifenthrin residues in milk samples. In the USA, Australia and Canada the skim milk is made when all the milk fat is removed from the raw milk by using a separator (7). The results of the current study were in agreement with (8). Who reported that skimming of buffaloes and cow's milk lead to a slight reduction in the analyzed pesticide concentration in skim milk. In addition, it was in agreement with (9) Pyrethroids range from nonpolar to low-polarity lipophilic compounds. Owing to their metabolism in animals, they tend to bio-accumulate in lipid compartments, becoming a potential source of human exposure through foodstuffs (8).

Table 1: Comparison of the mean levels of deltamethrin and bifenthrin residues (ppm) between the cow's raw and skimmed milk samples collected from the Abu-Ghraib dairy plant

\begin{tabular}{lccccc}
\hline Source of samples & $\begin{array}{c}\text { No. of xamined } \\
\text { samples }\end{array}$ & $\begin{array}{c}\text { Fat\% } \\
\text { Mean }\end{array}$ & $\begin{array}{c}\text { Deltamethrin }(\mathrm{ppm}) \\
\text { Mean } \pm \text { S.E }\end{array}$ & $\begin{array}{c}\text { Bifenthrin (ppm) } \\
\text { Mean } \pm \text { S.E }\end{array}$ & $\begin{array}{c}\text { \%violation } \\
\text { MRLs 0.05 }\end{array}$ \\
\hline Whole milk & 5 & 3.29 & $0.113 \pm 0.22 \mathrm{~A}$ & $0.134 \pm 0.31 \mathrm{a}$ & $100 \%$ \\
Skimmed milk & 5 & 1.064 & $0.0 \pm 0.0 \mathrm{~B}$ & $0.0 \pm 0.0 \mathrm{~b}$ & $\mathrm{NV}^{*}$ \\
\hline
\end{tabular}

The effect of different industrial heat treatments on the degradation of the deltamethrin and bifenthrin residues (ppm) in cow's milk

Exposure of raw milk samples to one of the industrial heat treatments such as $63 \mathrm{C}^{\circ} / 30 \mathrm{~min}, 80 \mathrm{C}^{\mathrm{o}} / 5 \mathrm{~min}$, and $100 \mathrm{C}^{\mathrm{o}} / 5$ min caused a significant $(\mathrm{P}<0.05)$ reduction in the concentrations of deltamethrin residues at the rate of $15 \%$, $35 \%$ and $78 \%$ respectively (Table 2). Boiling of the raw milk samples for 5 minutes offered an effective approach since it greatly reduced the levels deltamethrin residues to less than the MRLs that recommended by the USA and European legislations (10-12). The degradation of the deltamethrin and bifenthrin residues in milk depends on both the time and degree of temperature treatment. The work of (13) revealed that high temperature of the food processing leads to the large reductions in pesticide levels in the milk product. Deltamethrin and bifenthrin were decreased in pasteurized raw milk samples and pasteurization was proved to be the least effective on the degradation or elimination of pesticide residues (8). Pasteurization has been reported to have very little effect on the Dichlorodiphenyltrichloroethane (DDT) levels in milk (14).

Table 2: The effect of different industrial heat treatments on the degradation of the deltamethrin and bifenthrinresidues (ppm) in cow's milk

\begin{tabular}{lccccc}
\hline Heat treatment & $\begin{array}{c}\text { N0.of samples } \\
\text { per product }\end{array}$ & $\begin{array}{c}\text { Fat \% } \\
\text { mean } \pm \text { SE }\end{array}$ & $\begin{array}{c}\text { Deltamethrin (ppm) } \\
\text { mean } \pm \text { SE }\end{array}$ & $\begin{array}{c}\text { Bifenthrin (ppm) } \\
\text { Mean } \pm \text { S.E }\end{array}$ & \% Reduction \\
\hline Room temp. $\left(30^{\circ} \mathrm{C}\right)$ & 3 & 4.85 & $0.180 \pm 0.003 \mathrm{~A}$ & $0.182 \pm 0.010 \mathrm{a}$ & $0 \%$ \\
$63^{\circ} \mathrm{C} / 30 \mathrm{~min}$ & 3 & 4.85 & $0.147 \pm 0.005 \mathrm{~B}$ & $0.152 \pm 0.006 \mathrm{~b}$ & $15 \%$ \\
$80^{\circ} \mathrm{C} / 5 \mathrm{~min}$ & 3 & 4.85 & $0.119 \pm 0.015 \mathrm{C}$ & $0.114 \pm 0.017 \mathrm{c}$ & $35 \%$ \\
$100^{\circ} \mathrm{C} / 5 \mathrm{~min}$ & 3 & 4.85 & $0.040 \pm 0.003 \mathrm{D}$ & $0.043 \pm 0.004 \mathrm{~d}$ & $78 \%$ \\
\hline
\end{tabular}

Deltamethrin and bifenthrin residues in raw milk samples of different animal species

The one way analysis of variance (ANOVA) revealed that there was a significant $(\mathrm{P}<0.05)$ seasonal variation of the deltamethrin and bifenthrin concentrations in milk samples for each animal species. All the milk samples collected from buffaloes, ewes, cows, goats and camels had significantly $(\mathrm{P}<0.05)$ higher mean levels of deltamethrin residues in summer season $(0.174,0.142,0.133,0.045$ and $0.032 \mathrm{ppm}$ respectively) and bifenthrin concentrations in milk samples for each animal species where all the milk samples that were collected from buffaloes, ewes, cows, 
goats and camels had significantly $(\mathrm{P}<0.05)$ higher mean levels of Bifenthrin residues in summer season $(0.152$, $0.124,0.117,0.043,0.038 \mathrm{ppm}$ respectively) than in winter season levels of deltamethrin residues in buffaloes, ewes, cows, goats and camels $(0.009,0.012,0.012,0.005$ and $0.002 \mathrm{ppm}$ respectively) and levels Bifenthrin residues in winter season in buffaloes, ewes, cows, goats and camels $(0.013,0.017,0.014,0.006,0.005 \mathrm{ppm}$ respectively). From obtained results in this study, it is obvious that all of the examined milk samples from buffaloes, ewes and cows in summer season were failed to conform to the standard MRLs as they exceeded the accepted MRLs of $0.05 \mathrm{ppm}$ (100\% violation) that recommended by the WHO and FAO for the deltamethrin and bifenthrin residues in milk samples as shown in table 3. From the obtained results, it was clearly obvious that the detectable concentrations of the deltamethrin were higher in buffalo's and ewe's milk samples than those found in cow's, goats and camels. The results could be attributed to the higher fat content of Buffalo's and Ewe's milk than the other animals as well as the lipophilic nature of the deltamethrin and bifenthrin $(15,16)$. Ashry et al. (17) reported that the pesticides residues were higher in Buffalo's milk than cow's milk since the fat contents of Buffalo's milk was on average twice as higher as that of cow's milk (18).

Deltamethrin and bifenthrin is fat soluble and either stored in adipose tissues or secreted in milk fat where residues of particularly organochlorine pesticides tend to accumulate in the body fat or enter to milk fat while the less lipophilic compounds and their metabolites may be excreted in the urine (19). The results of this study is similar to the study of Jackson Ombui (20) and a Sara and Najim (1).

Table 3: Seasonal variation of the mean levels of deltamethrin and bifenthrin residues (PPM) in raw milk samples of different animal species collected from Abu-Ghraib village.

\begin{tabular}{|c|c|c|c|c|c|c|c|c|c|}
\hline \multirow{2}{*}{$\begin{array}{l}\text { Source of } \\
\text { milk } \\
\text { samples }\end{array}$} & \multirow{2}{*}{$\begin{array}{c}\text { No. Of } \\
\text { examined } \\
\text { samples }\end{array}$} & \multicolumn{4}{|c|}{ Summer } & \multicolumn{4}{|c|}{ Winter } \\
\hline & & $\begin{array}{c}\text { Fat } \\
\%\end{array}$ & $\begin{array}{l}\text { Deltamethrin } \\
\text { residues } \\
\text { Mean } \pm \text { SE }\end{array}$ & $\begin{array}{l}\text { Bifenthrin } \\
\text { residues } \\
\text { Mean } \pm \text { SE }\end{array}$ & $\begin{array}{c}\% \\
\text { violation } \\
\text { MRLs } \\
0.05 \\
\end{array}$ & $\begin{array}{c}\text { Fat } \\
\%\end{array}$ & $\begin{array}{l}\text { Deltamethrin } \\
\text { residues } \\
\text { Mean } \pm \text { SE }\end{array}$ & $\begin{array}{l}\text { Bifenthrin } \\
\text { residues } \\
\text { Mean } \pm \text { SE }\end{array}$ & $\begin{array}{c}\% \\
\text { violation } \\
\text { MRLs } \\
0.05 \\
\end{array}$ \\
\hline Buffaloes & 5 & 6.85 & $3 \mathrm{Aa}$ & $02 \mathrm{Ca}$ & $100 \%$ & 7.17 & $03 \mathrm{~B}$ & $0.013 \pm$ & $\mathrm{NV}^{*}$ \\
\hline & - & & $\mathrm{Ab}$ & & & 5.95 & B & $+\mathrm{Da}$ & $\mathrm{NV}^{*}$ \\
\hline $\mathrm{C}$ & 5 & 81 & $\mathrm{Ab}$ & 0.11 & $100 \%$ & 3.3 & $3 \mathrm{~B}$ & 0.01 & $\mathrm{NV}^{*}$ \\
\hline Goa & 5 & 82 & $9 \mathrm{Ac}$ & 0.043 & $\mathrm{NV}^{*}$ & 2.56 & 0.00 & $0.006 \pm$ & $\mathrm{NV}^{*}$ \\
\hline Camels & 5 & 2.54 & $0.032 \pm 0.013 \mathrm{Ac}$ & $0.038 \pm 0.009 \mathrm{Cc}$ & $\mathrm{NV}^{*}$ & 2.33 & $0.002 \pm 0.003 \mathrm{~B}$ & $0.005 \pm 0.001$ & $\mathrm{NV}^{*}$ \\
\hline
\end{tabular}

Seasonal variation of the mean levels of deltamethrin and bifenthrin residues (ppm) in breast milk sample collected from al-sader and al-karada districts

The data/ illustrated in the Table 4 was shown the mean levels of deltamethrin residues in the Breast milk samples that were collected from both AL-Sader and AL-Karada districts during the two climatic periods (3 samples/ district/ season). Overall, one way analysis of variance (ANOVA) revealed that there was a significant $(\mathrm{P}<0.05)$ differences between the mean levels of deltamethrin residues in milk samples that were collected from AL-Sader and AL-Karada districts during the summer season, where milk samples that were collected from AL-Sader district which recorded significantly $(\mathrm{P}<0.05)$ during the summer season.

According to the seasone, the results showed that the statistically significantly $(\mathrm{P}<0.05)$ were influence by the concentrations of the deltamethrin residues in Breast milk samples. Data illustrated in Table 4 revealed that there was a seasonal variation in the mean levels of deltamethrin residues in breast milk samples for each district village where all the milk samples collected from AL-Sader and AL-Karada districts had significantly $(\mathrm{P}<0.05)$ the higher mean levels values of deltamethrin residues in summer season were $(0.024$ and $0.020 \mathrm{ppm}$ respectively) while, in winter season were $(0.0$ and $0.0 \mathrm{ppm}$ respectively). The bifenthrin residues in summer season were $(0.0231$ and $0.0153 \mathrm{ppm}$ respectively). While, in winter season were ( 0.0 and $0.0 \mathrm{ppm}$ respectively).because most farmers used the pesticides during the summer season much more than the other seasons (21).

Generally the results further demonstrated that all of the examined breast milk samples from the above mentioned two districts in summer season did not exceed the accepted MRLs of 0.05 ppmthat recommended by the WHO and FAO (18). 
Table 4: Seasonal variation of the mean levels of deltamethrin and bifenthrin residues (PPM) in Breast milk sample collected from AL- Sader and AL-Karada districts.

\begin{tabular}{|c|c|c|c|c|c|c|c|c|c|}
\hline \multirow{2}{*}{$\begin{array}{l}\text { Source of } \\
\text { milk } \\
\text { samples }\end{array}$} & \multirow{2}{*}{$\begin{array}{c}\text { No. of } \\
\text { examined } \\
\text { samples } \\
\text { per season }\end{array}$} & \multicolumn{4}{|c|}{ Summer } & \multicolumn{4}{|c|}{ Winter } \\
\hline & & $\begin{array}{l}\text { Fat } \\
\%\end{array}$ & $\begin{array}{l}\text { Deltamethrin } \\
\text { residues } \\
\text { Mean } \pm \text { SE }\end{array}$ & $\begin{array}{l}\text { Bifenthrin } \\
\text { residues } \\
\text { Mean } \pm \text { SE }\end{array}$ & $\begin{array}{c}\% \\
\text { violation } \\
\text { MRLs } \\
0.05\end{array}$ & $\begin{array}{c}\text { Fat } \\
\%\end{array}$ & $\begin{array}{l}\text { Deltamethrin } \\
\text { residues } \\
\text { Mean } \pm S E\end{array}$ & $\begin{array}{l}\text { Bifenthrin } \\
\text { residues } \\
\text { Mean } \pm \text { SE }\end{array}$ & $\begin{array}{c}\% \\
\text { violation } \\
\text { MRLs } \\
0.05\end{array}$ \\
\hline $\begin{array}{l}\text { AL-Sader } \\
\text { district }\end{array}$ & 6 & 2.75 & $\begin{array}{c}0.024 \pm 0.002 \\
\mathrm{Aa}\end{array}$ & $\begin{array}{c}0.0231 \pm 0.003 \\
\mathrm{Ca}\end{array}$ & $\mathrm{NV}^{*}$ & 2.60 & $\begin{array}{l}0.0 \\
\mathrm{~B}\end{array}$ & $\begin{array}{c}0.0 \\
D\end{array}$ & $\mathrm{NV}^{*}$ \\
\hline $\begin{array}{l}\text { AL-Karada } \\
\text { district }\end{array}$ & 6 & 2.85 & $\begin{array}{c}0.020 \pm 0.003 \\
\mathrm{Ab}\end{array}$ & $\begin{array}{c}0.0153 \pm 0.007 \\
\mathrm{Cb}\end{array}$ & $\mathrm{NV}^{*}$ & 2.75 & $\begin{array}{c}0.0 \\
\mathrm{~B}\end{array}$ & $\begin{array}{c}0.0 \\
\mathrm{D}\end{array}$ & $\mathrm{NV}^{*}$ \\
\hline Total & 12 & 2.8 & 0.022 & 0.0192 & $\mathrm{NV}^{*}$ & 2.67 & 0.0 & 0.0 & $\mathrm{NV}^{*}$ \\
\hline
\end{tabular}

\section{References}

1. Sara A A, Najim HN. Determination of insecticide deltamethrin residues in local and imported raw milk samples collected from different animal's species and the effect of processing heat treatment on its content in milk. Iraqi J Vet Med. 2017;41(1):49-54.

2. Pranschke AM, Hooper-Bui LM, Moser B. Efficacy of bifenthrin treatment zones against red imported fire ant.J Econ Entomol. 2003;96(1):98-105.

3. Environmental Protection Agency. Bifenthrin Summary Document. http://www.regulations.gov/search/Regs/home.html [Accessed 7-0910]. June 2010

4. Aba-Zahw M, Abd El-Kader M, Hagazy M, Mansour M. Pesticide residues in butter and ghee. Bull of Suez Canal University. Appl Sci. 1993;2(1):40-48.

5. Rivezzi G, Piscitelli P, Scortichini G, Giovannini A, Diletti G, Migliorati G, Black DM. A general model of dioxin contamination in breast milk: results from a study on 94 women from the Caserta and Naples areas in Italy. Inter $\mathbf{J}$ Environ Res Public Health. 2013;10(11):5953-5970.

6. Snedecor, G.W. and Cochran, W.G., Statistical Methods. 7th Edition, Iowa State University Press, Ames., 1980.

7. Nag SK, Raikwar MK. Persistent organochlorine pesticide residues in animal feed. Environ Monit Assess. 2010;174(1-4):1460-1461.

8. CFR - Code of Federal Regulations 2015.

9. LeDoux M. Analytical methods applied to the determination of pesticide residues in foods of animal origin. A review of the past two decades. J Chromatog A, 2011;1218(8):1021-1036.

10. Abou-Arab AAK. Microbiological and compositional quality of dairy products in relation to some pollutants. PhD Thesis, Faculty of Agriculture Ain-Shams University. 1991.
11. Hugunin AG, Bradley RL. Distribution of organochlorine pesticides among some milk components. J Dairy Sci. 1971;54(3):355-359.

12. El-Alfy MBS. Studies on the residues of insecticides in some foods. MSc. Faculty of Agriculture, Moshtohor, Zagazig University. 1981.

13. Kaushik G, Satya S, Naik SN. Food processing a tool to pesticide residue dissipation-A review. Food Res Intern. 2009;42(1):26-40.

14. Ritchey SJ, Young RW, Essary EO. Effects of heating and cooking method on chlorinated hydrocarbon residues in chicken tissues. J Agricul Food Chem. 1972;20(2): 291-293.

15. Shahzadi N, Imran M, Sarwar M, Hashmi AS, Wasim M. Identification of pesticides residues in different samples of milk. J Agroalim Proce Technol. 2013;19(2):167-172.

16. Neelam S, Muhammad I, Mohammad S, Abu Saeed H, Muhammad W. J Agroalim Proce Technol. 2013;19(2):167-172.

17. Ashry MA, Bayoumi OC, El-Fakharany II, Derbalah AS, Ismail AA. Monitoring and removal of pesticides residues in drinking water collected from Kafr El-Sheikh governorate. Egypt $J$ Agric Res Tanta Univ. 2006;32(3):691-704.

18. FAO/WHO. Pesticide residue in food. Scientific Basis for Codex. Online Database www.fao.org/publications. 2016.

19. Jahed Khaniki G. Aflatoxin M1 related to consumption of contaminated milk and dairy products. J Iran Vet Council. 2007.

20. Ombui JN. Consultancy on analysis of heavymetals, drugs and pesticide residues and aflatoxinm1 in camel milk., 2013.

21. Hongjun Leia, Hongwei Pana B, Beidou Xi. Pesticides pollution characteristics in the soil-groundwater system of vegetable greenhouse cultivation in eastern China. J Chem Pharmac Res. 2014;6(6):369373. 